\title{
EXCEL VBA FÜGGVÉNY KIALAKÍTÁSA FONTOSABB IRRACIONÁLIS SZÁMOK FELISMERÉSÉRE
}

\author{
Fabulya Zoltán
}

\begin{abstract}
Absztrakt: Számítások során sokszor kapunk eredményként irracionális értéket, melynek megjelenítése tizedes tört alakban látható számológépünk vagy számítógépünk kijelzőjén. Viszont így nehezen értelmezhető az érték és pontatlan is. Ezért készítettünk olyan Excel függvényt, hogy a fontosabb irracionális értéken alapuló számokat, mint egy egész szám gyökeként vagy a Pi szám racionális törttel szorzásakor adódó irracionális számokat, meg tudjuk jeleníteni a „," (gyök) vagy a „, $\pi$ (Pi) karakterek segítségével. A programozás során kifejlesztett algoritmusok a Microsoft Excel táblázatkezelö program Visual Basic for Applications szolgáltatásával készültek el. A szám megfelelö megjelenítéséhez a függvényünknek fel kell ismernie az argumentumaként kapott számot, melyet szöveges formátumban jelenít meg rövidebb, és jobban értelmezhető formában, mint az eredeti, tizedes tört alakú irracionális szám.
\end{abstract}

Abstract: During calculations, we often get an irrational value, the display of which is shown as a decimal fraction on the display of our calculator or computer. However, the value is difficult to interpret and inaccurate. Therefore, we created an Excel function so that numbers based on a major irrational value, such as irrational numbers resulting from the root of an integer or the number of Pi multiplied by a rational fraction, can be represented by the characters " $\sqrt{ }$ " (root) or " $\pi$ " (Pi). The algorithms developed during programming were developed using the Visual Basic for Applications feature of the Microsoft Excel spreadsheet program. To display the number properly, our function must recognize the number obtained as an argument, which it displays in text format in a shorter and more interpretable form than the original, decimal fractional irrational number.

Kulcsszavak: irracionális szám, Excel VBA, programozás, függvény, gyök felismerése

Keywords: irrational number, Excel VBA, programming, function, root recognition

\section{Bevezetés}

Az irracionális számok tizedes tört alakban jelennek meg elektronikus eszközeink kijelzőjén. Szükségszerüen így a pontos érték nem lesz kiolvasható, mert végtelen számú tizedes számjegy alkotja az irracionális számokat, melyben a végtelenségig ismétlődő szakasz sincs (Obádovics, 2012). Ilyen a Pi $(\pi)$ szám is, de gyökvonás eredményeként szintén irracionális szám adódik még az egész számok esetén is, ha az nem négyzetszám. Rövidebb, jobban értelmezhető és pontos az irracionális szám, ha a megfelelő szimbólumokat, például a gyök $(\sqrt{ })$ vagy a Pi $(\pi)$ karaktereket alkalmazzuk a leírásuk során. Ezt a fajta megjelenítést viszont a programjaink nem támogatják.

A szögek megadása sokszor radián mértékegységben szükséges. Egy nevezetes szög tizedes tört alakja radiánban szinte értelmezhetetlen, mint ahogy ez látható az (1) képletben.

$$
30^{\circ}=\frac{\pi}{6}=0,523598775598299
$$


A trigonometrikus függvények értékei nevezetes szögek esetében könnyebben értelmezhetök gyökös formában (2).

$$
\cos 30^{\circ}=\frac{\sqrt{3}}{2}=0,866025403784439
$$

A fenti képletekben egyenletszerkesztő biztosította a megfelelő megjelenítést, de karakteres mód is alkalmazható $(\pi / 6, \sqrt{ } 3 / 2)$. Ez a mód már lehetővé teszi, hogy az Excel táblázatkezelő programban karakteresen, szöveg típusúan kiolvasható legyen egy számítás eredményeként kapott, tizedes tört alakú szám. Ebben a cikkben bemutatásra kerül a legfontosabb típusú irracionális számok karakteres módú kijelzéséhez szükséges Excel munkalapfüggvény kialakítása, melynek lényeges eleme, a számok felismerését biztosító algoritmus kifejlesztése a Visual Basic for Applications (VBA) által nyújtott fejlesztői környezetben. Számos cikk kutatása használja az Excel VBA lehetöségeit (Hampel, 2017; Hampel, 2018).

Mivel végtelen sok irracionális szám van, s köztük olyanok is, melyek nem jeleníthetők meg speciális karakterek segítségével, ezért csak néhány, fontosabb típusú irracionális szám felismerésével foglalkozunk, melyek a következő alakúak (3) és (4).

$$
\begin{aligned}
& \frac{m}{n} \cdot \pi \\
& \frac{m}{n} \cdot \sqrt{a}
\end{aligned}
$$

ahol:

$$
\begin{aligned}
& m=\text { egész szám } \\
& n=\text { pozitív egész szám }(1 \leq n) \\
& a=\text { pozitív egész szám }(1 \leq a)
\end{aligned}
$$

Tehát vagy a Pi számon, vagy egy egész szám négyzetgyökén alapul a felismerendő irracionális szám. Az $n$ és $a$ számok esetén további korlátozás szükséges, hiszen a végtelenségig nem terjeszthetjük ki a felismerést. A tesztek során a 100 felső korlát elegendőnek bizonyult. Azért szükséges, hogy $m$ és $n$ egész számok legyenek, hogy a megjelenítési problémát okozó irracionális érték csak a Pi vagy a gyökvonás eredménye lehessen.

\section{Anyag és módszer}

A kutatásunk elméleti háttere az irracionális számok ismeretkörébe tartozik, míg a programozási feladatokhoz az Excel VBA áttekintése szükséges.

\subsection{Irracionális számok}

Definíció szerint, az irracionális számok azok a valós számok, melyek nem írhatók fel két egész szám hányadosaként. Ismeretes, hogy a $\pi$ és a $\sqrt{2}$ irracionális számok. 
Könnyen bizonyítható, hogy a pozitív egész számok négyzetgyöke is irracionális, kivéve a négyzetszámokat, melyek négyzetgyöke egész szám (Obádovics, 2012).

$\mathrm{Az}$ irracionális számok végtelen számú tizedesjegyből állnak, ismétlődő szakaszok nélkül. Emiatt nem írható le a pontos értékük tizedes tört alakban, de tetszőleges pontosság elérhető a tizedesjegyek számának növelésével. Így viszont hosszabb lesz a leírt szám.

Az irracionális számok egy fontos csoportját azok képezik, melyek egy racionális szám négyzetgyökeként adódnak. Egy másik csoportjuk azok, melyek radián mértékegységben egy olyan szöget jelölnek, melyek racionális értékkel adhatók meg fok mértékegység esetén. Mint később látni fogjuk, ezek az irracionális számok felírhatók a (3) vagy a (4) képlettel megadott formában. Célunk olyan Excel VBA függvény kifejlesztése, mellyel megjeleníthető ilyen alakban egy irracionális szám, ha ez egyáltalán lehetséges.

\subsection{Az Excel VBA}

Az Excel táblázatkezelő program használata során jellemzően számított eredményekre van szükségünk. Ekkor formulákat és munkalapfüggvényeket alkalmazunk. Viszont arra is van lehetöségünk, hogy saját függvényeket hozzunk létre (Kovalcsik, 2005). Ehhez programoznunk kell a Visual Basic for Applications szolgáltatást kihasználva, mely a Basic programozási nyelven alapul. A függvények névvel rendelkeznek, és az argumentumukban szereplő változóktól függő eredményt adnak (Matteson, 1995). Általános alakjuk:

Public Function függvénynév(argumentumok)

utasítások

függvénynév = érték

\section{End Function}

A függvények használatakor meg kell adnunk az argumentumuk értékét. Az utasítások végrehajtásával kialakul egy érték, mely a függvény eredménye lesz a függvénynév = érték utasítás miatt.

A függvényben szereplő utasítások alapesetben egyszer, egymás után hajtódnak végre. Ezt nevezzük szekvenciális utasítás szerkezetnek, melynek a következö az alakja (Kovalcsik, 2005):

...

utasítás 1

utasítás 2

utasítás 3

Szelekciós szerkezetre van szükségünk akkor, amikor feltételtől függ az utasítás végrehajtása (Kovalcsik, 2005):

If feltétel Then

utasítások1

Else

utasítások2

End If 
Ekkor a feltétel teljesülésekor az utasítások1 blokk utasításai hajtódnak végre, ellenkező esetben pedig az utasítások2 blokké.

Iterációs szerkezetre van szükségünk a programunkban akkor, amikor többször szükséges végrehajtani egy utasítást (Kovalcsik, 2005). Az alábbi feltételes ciklus szerkezetben a feltétel teljesüléséig az utasítások ismételt végrehajtása történik meg:

While feltétel

utasítások

Wend

A fent leírt szekvenciális, szelekciós és iterációs szerkezetekkel bármely program megvalósítható.

\subsection{Kereső algoritmus}

Munkánk lényeges pillére, hogy egy számról felismerjük azt, hogy előállítható-e a számunkra szükséges formában. Ezt a feladatot egy kereső algoritmussal oldhatjuk meg. Ennek lényege, hogy a rendelkezésre álló elemek listájából kikeresi azt, mely megfelel a feltéteknek, ha egyáltalán van ilyen közöttük. Ezt úgy végezhetjük el, hogy az elemeket egyenként vizsgáljuk mindaddig, míg vagy el nem fogynak, vagy nem találunk megfelelőt (Walkenbach, 2013). Ez megvalósítható egy feltételes ciklus szerkezettel. A ciklus befejezésekor még egy szelekciós szerkezettel vizsgáljuk meg, hogy a ciklus sikeres keresés miatt fejeződött be, vagy azért, mert elfogytak a lista elemei. Az algoritmus pszeudokódja az alábbi:

Legyen a vizsgálandó elem a lista első eleme

While a vizsgálandó elem nem megfelelő és

$$
\text { van még nem vī̄sgált elem }
$$

Legyen a vizsgálandó elem a lista következő eleme Wend

If a vizsgálandó elem megfelelő Then

A találat a vizsgálandó elem

Else

Nincs találat

End If

\section{Eredmények}

A kutató munka során meg kell vizsgálnunk, hogy milyen feltételek mellett mondhatjuk egy számról, hogy a (3) vagy (4) formában felírhatók. Erre azért van szükség, hogy lehetőleg ne korlátozzuk az adott formában megjeleníthető számok körét. A további feladatunk a szükséges algoritmusok programjának elkészítése, melynek utolsó fázisa annak az Excel munkalapon használható függvénynek az elkészítése, mely a szám megjelenítését eredményezi az adott (3) vagy (4) formátumban. 


\subsection{A pontosan megjeleníthető irracionális számok}

Rövid és pontos csak úgy lehet egy irracionális szám megadása, ha kifejezhető véges jelsorozattal leírható, ismert értékü irracionális számként, vagy annak véges jelsorozattal leírható függvényeként. A (3) vagy (4) forma esetén a Pi vagy a gyök jel szükséges ehhez.

Elsőként azt látjuk be, hogy bármely olyan szögérték, mely fok mértékegységben racionális számmal $\left(\frac{p}{q}\right)$ megadható, az felírható a (3) formában, ahogy ez az (5) levezetésben látható.

ahol:

$$
\frac{p}{q}\left[^{\circ}\right]=\frac{p}{q} \cdot \frac{\pi}{180}[\mathrm{rad}]=\frac{p}{180 \cdot q} \cdot \pi[\mathrm{rad}]=\frac{m}{n} \cdot \pi[\mathrm{rad}]
$$

$$
\begin{aligned}
& p=\text { egész szám } \\
& q=\text { pozitív egész szám }(1 \leq q) \\
& m=\text { egész szám }(m=p) \\
& n=\text { pozitív egész } \operatorname{szám}(n=180 \cdot q)
\end{aligned}
$$

A (6) levezetésben az látható, hogy nem csak egy nem negatív egész szám gyöke, de bármely nem negatív racionális szám gyöke is felírható a (4) formában.

ahol:

$$
\sqrt{\frac{p}{q}}=\sqrt{\frac{p \cdot q}{q^{2}}}=\frac{\sqrt{p \cdot q}}{q}=\frac{1}{q} \cdot \sqrt{p \cdot q}=\frac{m}{n} \cdot \sqrt{a}
$$

$$
\begin{aligned}
& p=\text { nem negatív egész szám } \\
& q=\text { pozitív egész szám }(1 \leq q) \\
& m=\text { egész szám }(m=1) \\
& n=\text { pozitív egész szám }(n=q) \\
& a=\text { pozitív egész szám }(1 \leq n=p \cdot q)
\end{aligned}
$$

A következő (7) levezetésben arra látunk példát, hogy egy egész szám gyöke akár többféle (4) alakban is megadható, kisebb egész szám gyökének segítségével.

$$
\begin{gathered}
\sqrt{32}=\sqrt{4 \cdot 8}=2 \cdot \sqrt{8} \\
\sqrt{32}=\sqrt{16 \cdot 2}=4 \cdot \sqrt{2}
\end{gathered}
$$

Olyan kereső algoritmust fejlesztünk ki, mely a legkisebb pozitív egész szám gyökeként biztosítja a (4) formát. 


\subsection{Az elkészített függvények}

Elsőként egy olyan univerzális kereső függvényt készítünk el, mely a (3) és a (4) alakok esetében is használható. Erre azért van lehetőségünk, mert ezek az alakok általánosíthatók, ahogy ezt a (8) képlet mutatja.

$$
\begin{aligned}
\frac{m}{n} \cdot \pi & =\frac{m}{n} \cdot y \\
\frac{m}{n} \cdot \sqrt{a} & =\frac{m}{n} \cdot y
\end{aligned}
$$

ahol:

$$
\begin{aligned}
& m=\text { egész szám } \\
& n=\text { pozitív egész szám }(1 \leq n) \\
& a=\text { pozitív egész szám }(1 \leq a) \\
& y=\text { általánosított érték }(y=\pi \text { vagy } y=\sqrt{a})
\end{aligned}
$$

A kereső algoritmusnak akkor kell sikeres keresést jeleznie, ha a felismerendő szám (x) elöállítható a (8) alakban, azaz teljesül a (9) összefüggés.

$$
\mathrm{x}=\frac{m}{n} \cdot y
$$

ahol:

$$
\begin{aligned}
& x=\text { a felismerendő szám } \\
& m=\text { egész szám } \\
& n=\text { pozitív egész szám }(1 \leq n) \\
& y=\text { általánosított érték }
\end{aligned}
$$

További érdekessége ennek az általánosításnak, hogy $y=1$ esetén a felismerendő számot két egész szám hányadosaként állíthatjuk elö.

A kereső függvényünk kétváltozós, $\mathrm{x}$ és y függvényében keres olyan n pozitív egész számot, melyre a (9) összefüggés teljesül valamilyen m egész szám esetén. A (9) átrendezésével adódó (10) azt mutatja, hogy $m$ értéke kiszámítható tetszőleges $n$ érték esetén, csak nem garantálható, hogy ez az m egész szám legyen. Éppen ezt fogja az algoritmusunk ellenőrizni, hogy a pontos egyenlőséget biztosító számláló $(s)$ egész szám-e, mert csak ekkor tekinthető megfelelőnek $(m=s)$

$$
\mathrm{x}=\frac{s}{n} \cdot y \Rightarrow s=\frac{n \cdot x}{y}
$$

ahol:

$$
\begin{aligned}
& x=\text { a felismerendő szám } \\
& s=\text { nem feltétlenül egész szám } \\
& n=\text { pozitív egész szám }(1 \leq n) \\
& y=\text { általánosított érték }
\end{aligned}
$$


Az alábbi kereső függvényünk azért kapta a nevezo nevet, mert azt a nevező értéket keresi és adja vissza eredményként, mely a kívánt megjelenítést biztosítja. Ha nem talál megfelelő nevezőt, akkor 0 lesz az eredmény.

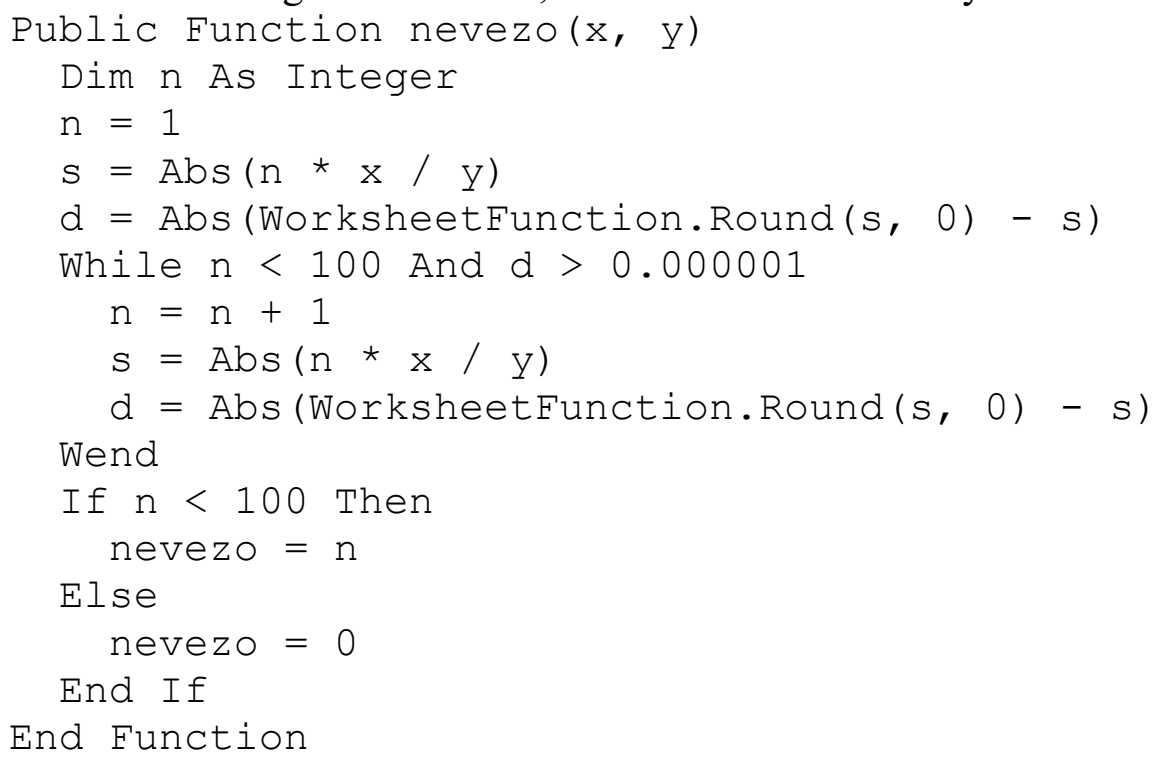

A függvény úgy ellenőrzi, hogy a (9) egyenlőséget biztosító $s$ érték egész-e, hogy megvizsgálja az egészre kerekített értékétől való eltérésének abszolútértékét, mint differenciát (d). Persze ennek 0-nak kellene lennie, ha $s$ egész, de a számítógépes számábrázolás pontatlansága miatt 0 -nak tekinthető egy nem negatív érték, ha nem nagyobb 0,000001-nél. Az egészre kerekítés a Round függvénnyel történik. A függvényünk az 1 értéktől kezdve egyesével növekvőleg keres alkalmas nevezőt, legfeljebb 100-ig. Így ha talál, akkor a legkisebbet fogja megtalálni.

A következő függvény azért kapta a s zamla lo nevet, mert a (9) alakú elöállítás számlálóját $(m)$ határozza meg abban az esetben, ha ez az előállítás létezik, vagyis találtunk alkalmas nevezőt. A számláló 0 értékü lesz, ha nincs ilyen nevezö.

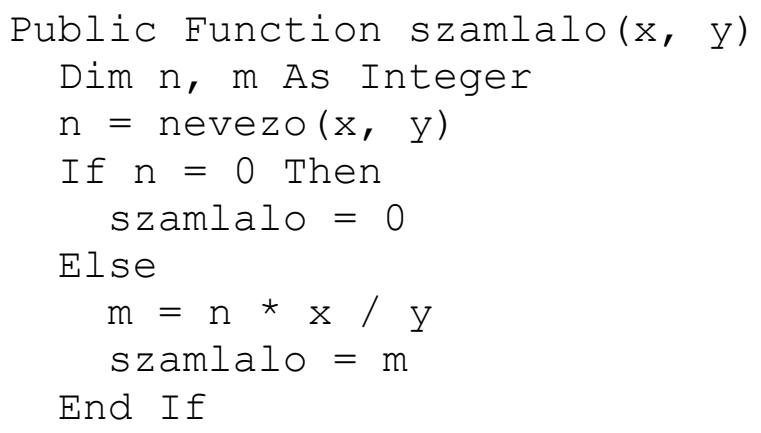

End Function

Még azokra a függvényekre van szükségünk, mellyel megtudhatjuk, hogy a felismerendő szám (x) előállítható-e a Pi vagy a gyök jelek egyikével, azaz a (3) vagy (4) formában. Ezek a pi_alap és gyok_a lap nevü függvények, melyek 0 értéket eredményeznek, ha nem lehetséges a kívánt alakú elóállítás. Az előállíthatóságot a nevezo függvény értékéből tudhatjuk meg az $y=\pi$ vagy az $y=\sqrt{a}$ 
alkalmasságából. Előállíthatóság esetén a függvények értéke az elő́llíthatóságot biztositó érték lesz, vagyis a Pi érték a pi_alap függvénynél, illetve az a érték a gyok_alap függvénynél. Viszont ez utóbbi szintén egy kereső algoritmus a megfelelő $a$ értékre, mely 1-tôl kezdve egyesével vizsgálandó. Így találat estén a legkisebb alkalmas értéket kapjuk még akkor is, ha több is alkalmas lett volna.

Public Function pi alap(x)

Dim n As Integer

$\mathrm{y}=$ WorksheetFunction.Pi

$\mathrm{n}=\operatorname{nevezo}(\mathrm{x}, \mathrm{y})$

If $\mathrm{n}=0$ Then

pi_alap $=0$

Else

$$
\underset{\text { End }}{\mathrm{pi} \text { If }} \text { alap }=\mathrm{y}
$$

End Function

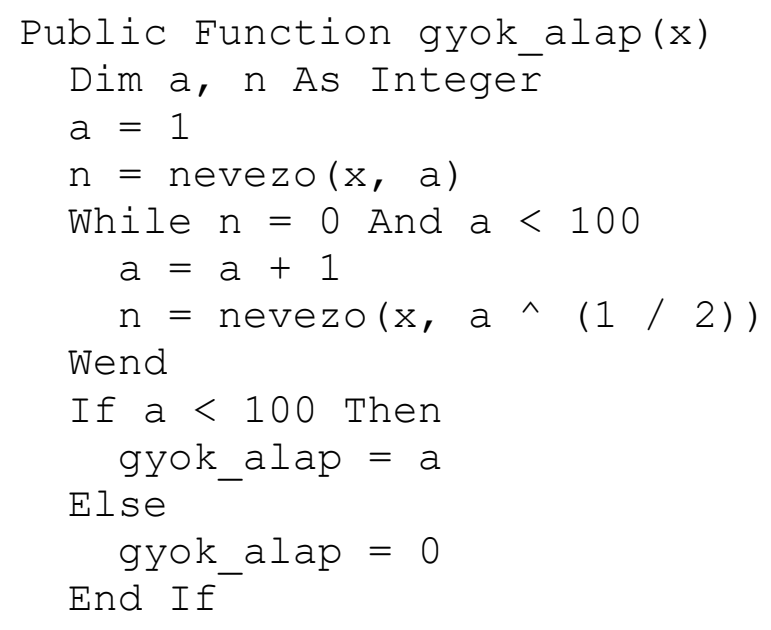

End Function

Az eddig elkészített függvényeket használjuk fel a végső, a felismerendő szám (3) vagy (4) alakú megjelenítését eredményező, txt_szam nevü függvényünknél. Ennek eredménye szöveges adattípusúként a megfelelő alak, ha az létezik, különben a szám 4 tizedesjeggyel.

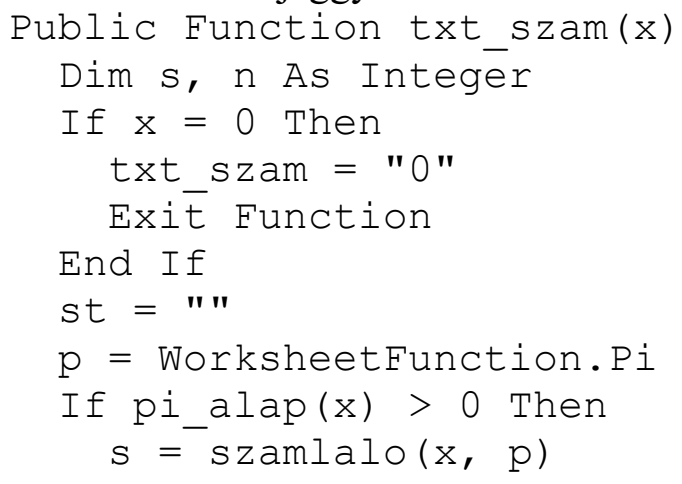




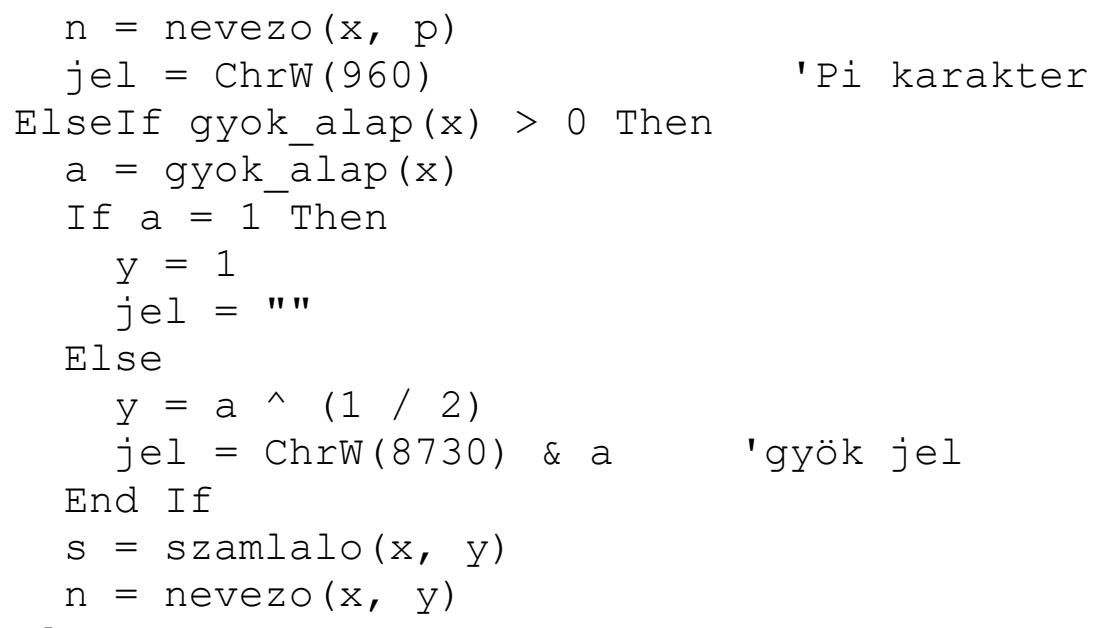

Else

txt_szam = " $"$ \& WorksheetFunction.Round $(x, 4)$

Exit Function

End If

If $s=-1$ Then

If jel = " "Then

st $="-1 "$

Else

st $="-" \&$ jel

End If

ElseIf $s=1$ Then

If jel = " "Then

st $=" 1 "$

Else

st $=$ jel

End If

Else

$s t=s \&$ jel

End If

If $n>1$ Then

st $=$ st $\& " / " \& n$

End If

txt_szam = st

End Function

A megjelenítés alakja több feltételtől függ:

- Elóállítható-e a szám, s ha igen, akkor melyik alakban.

- Ha a számláló értéke 1, akkor csak olyan esetben szükséges a megjelenítése, ha a felismert érték racionális (például 1/4). Irracionális esetben elegendő az 1 érték nélkül a Pi vagy a gyökérték megjelenítése a számlálóban (például $\pi / 4$ vagy $\sqrt{ } 3 / 2$ ).

- A nevezőt nem kell megjeleníteni, ha 1 az értéke, de ekkor a számláló szükséges olyan esetben, ha 1 számlálójú és racionális értékü. 
- Negatív szám esetén kell az előjel, különben nem.

Az 1. táblázatban néhány szám esetén látható a függvényünkkel kapott megjelenítésük.

\section{1. táblázat: Néhány felismert szám és megjelenítésük}

\begin{tabular}{|l|l|}
\hline A szám értéke & A szám megjelenítése \\
\hline 1,13137085 & $4 \sqrt{2} / 5$ \\
\hline 12,12435565 & $7 \sqrt{3}$ \\
\hline 4,188790205 & $4 \pi / 3$ \\
\hline 4,294117647 & $73 / 17$ \\
\hline
\end{tabular}

Forrás: a szerző saját szerkesztése.

\section{Következtetések}

A Microsoft Excel táblázatkezelő programhoz olyan munkalapfüggvényt alakítottunk ki, mely képes a legfontosabb típusú irracionális számok esetén is a pontatlan és nehezen értelmezhető tizedes tört alak helyett olyan megjelenítésükre, mely jobban áttekinthető, rövidebb és a pontos értéket jelzi. A felismerhető számok köre igényeinknek megfelelön bővíthető például a harmadik és negyedik gyök segítségével megjeleníthető irracionális számokkal. A kifejlesztett függvényt bármely Excel táblázatunkban felhasználhatjuk az eredmények könnyebb értelmezéséhez, ahol ez szükséges lehet.

\section{Irodalomjegyzék}

Hampel Gy. (2017): Excel VBA alkalmazása egy biometriai esettanulmány példáján bemutatva, Jelenkori társadalmi és gazdasági folyamatok, 12 (4): 35-40.

Hampel Gy. (2018): Egymintás t-próba programozható kialakítása Excel VBA környezetben, Jelenkori társadalmi és gazdasági folyamatok, 13 (3-4): 169-175.

Kovalcsik G. (2005): Az Excel programozása. Computerbooks, Budapest.

Matteson B. L. (1995): Microsoft Excel Visual Basic Programmer's Guide. MicrosoftPress, Washington.

Obádovics J. Gyula (2012): Matematika. Középiskolai tanulók, fóiskolai és egyetemi hallgatók, valamint müszaki és gazdasági szakemberek számára, gyakorlati alkalmazásokkal. Tizenkilencedik, bővített kiadás. Scolar Kiadó, Budapest.

Walkenbach, J. (2013): Excel VBA Programming for Dummies. 3rd edition. John Wiley \& Sons Inc., New Jersey. 